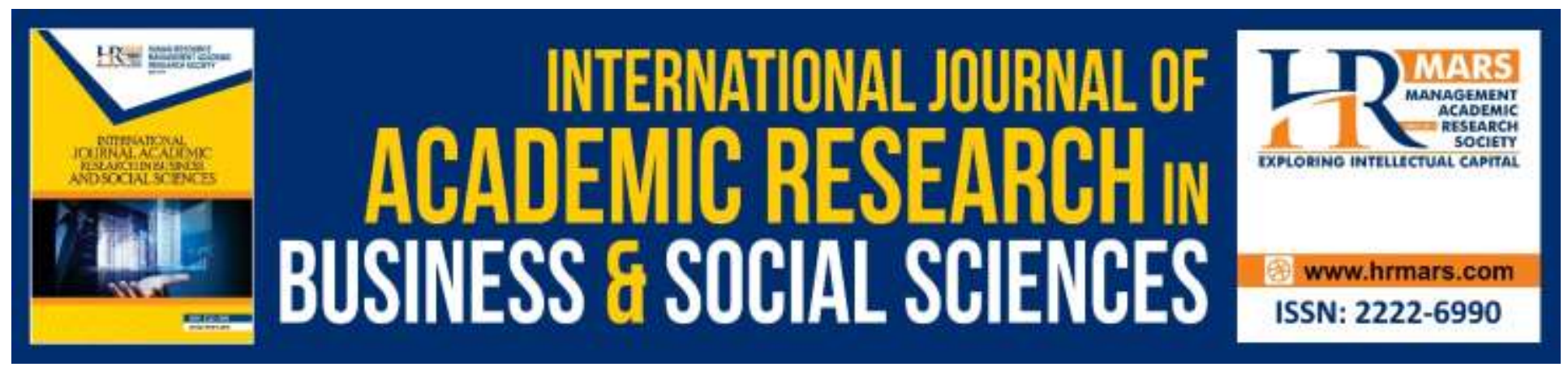

\title{
The Prospect of Teaching and Learning Engineering Mathematical Courses using Learning Tool
}

Norlenda Mohd Noor, Zuraida Alwadood, Hanifah Sulaiman, Suhaila Abd Halim

To Link this Article: http://dx.doi.org/10.6007/IJARBSS/v9-i7/6143 DOI: $10.6007 /$ IJARBSS/v9-i7/6143

Received: 22 May 2019, Revised: 23 June 2019, Accepted: 10 July 2019

Published Online: 30 July 2019

In-Text Citation: (Noor, Alwadood, Sulaiman, \& Halim, 2019)

To Cite this Article: Noor, N. M., Alwadood, Z., Sulaiman, H., \& Halim, S. A. (2019). The Prospect of Teaching and Learning Engineering Mathematical Courses using Learning Tool. International Journal of Academic Research in Business and Social Sciences, 9(7), 510-519.

Copyright: (C) 2019 The Author(s)

Published by Human Resource Management Academic Research Society (www.hrmars.com)

This article is published under the Creative Commons Attribution (CC BY 4.0) license. Anyone may reproduce, distribute, translate and create derivative works of this article (for both commercial and non-commercial purposes), subject to full attribution to the original publication and authors. The full terms of this license may be seen

at: http://creativecommons.org/licences/by/4.0/legalcode

Vol. 9, No. 7, 2019, Pg. 510 - 519

http://hrmars.com/index.php/pages/detail/IJARBSS

JOURNAL HOMEPAGE

Full Terms \& Conditions of access and use can be found at http://hrmars.com/index.php/pages/detail/publication-ethics 




\title{
The Prospect of Teaching and Learning Engineering Mathematical Courses using Learning Tool
}

\author{
Norlenda Mohd Noor, Zuraida Alwadood, Hanifah Sulaiman, Suhaila \\ Abd Halim
}

Fakulti Sains Komputer dan Matematik, Universiti Teknologi MARA Shah Alam, Malaysia

\begin{abstract}
Mathematic is often perceived as difficult subject by most students, even from engineering background. However, previous studies have shown that technology has proven to help students learn mathematics in a fun and easy way. In this study, we developed a learning tool with the objective to determine the prospect of learning engineering mathematical courses using an interactive learning tool developed with Maple 2016. We also measure the inclination of using the tool as part of teaching and learning in classroom. There are 40 Students from 2 different classes took part in the study. They are in the fourth semester of engineering program at a selected local university. The process starts by briefing the students on how to use the tool. Students are then answering several questions on a selected topic from vector calculus chapter. Later, they were given a set of two-part questionnaire. The first part was used to investigate the students' perception on the learning tool. The second part was used to evaluate the students' willingness in using the tool in classroom for solving vector calculus problems. While the tool require some improvements, students are likely to use it as part of learning in classroom.
\end{abstract}

Keywords: Learning Tool, Maple, Mathematical Engineering Courses

\section{Introduction}

E-learning can be defined in several ways. Almanasreh (2017) defined e-learning as a form of distance learning, where the time and geographical flexibility are preserved. Meanwhile, Rosenberg (2006) defines e-learning as the use of internet technologies to deliver a broad array of solutions that enhance knowledge and performance. Even with slightly different definition of the term, the idea of e-learning in general is to provide a different medium of learning to students, rather than the conventional way of teaching and learning. Studies have shown that e-learning is beneficial and should be part of the current education process. Although it is indisputable that e-learning requires teamwork at all levels in the organization and individual involved (Hussain 2004). For e-learning to be successful, the environment must be in place, also instructors and students must be ready.

There are many mathematical learning tool developed previously to assist teaching and learning process. Ozyurt, Ozyurt, Baki, and Guven (2013) developed UZWEBMAT for learning 
INTERNATIONAL JOURNAL OF ACADEMIC RESEARCH IN BUSINESS AND SOCIAL SCIENCES Vol. 9, No. 7, July, 2019, E-ISSN: 2222-6990 @ 2019 HRMARS

probability subjects, which provides most appropriate environment for students. In addition, UZWEBMAT can be used as well to reinforce traditional classroom education. Abdulameer, Sulaiman, Aras and Saleem (2016) on the other hands developed a GUI control system analysis to assist engineering students and practicing engineers using MATLAB. Study by Naidoo and Naidoo (2007) suggested that blended learning can enhances understanding of key concepts in elementary calculus based on their research of implementing computer laboratory teaching environment. There are practically more than that. As simple as using calculator for learning integral (Zakaria and Salleh 2015). And, there is also other mathematical software available to help student working with complicated problems, such as Maple and Mathematica. Some require a bit of programming skills and some are user friendly. Jono et al. (2016) mentioned that students generally found interactive multimedia is interesting as it captures and holds learners' interests which consequently attract the students to get involved into it. This attractiveness is due to its multi-sensory characteristics in terms of sounds, images and text. In addition, this type of learning tool navigates the students to build their own unique mental structures based on their exploration.

Mathematic, especially calculus is always perceived as a difficult subject. Student with engineering background are believed to possess a sound mathematical basic knowledge in order to succeed in their chosen programme. They also need different skills and abilities in order to construct the solution in multi-step of processes (Adam et al. 2017). But unfortunately, recent survey shows that it is not the case. For a few semesters, high failure rate of a mathematical engineering calculus has been recorded, ranging from $25 \%$ to $45 \%$ (Noor et al. 2018). The rate is significantly increasing. Among factors that contributed to that high failure rate are poor mathematics background, problems in memorizing formulas, misunderstood concept and mathematics anxieties (Noor et al. 2018). Class absenteeism is also one of the main factors that leads to lack of thorough knowledge of the subject (Prakash et al. 2014). Osman and Pa (2015) have found that students used the universal integrated perspective to interpret the acquisition of mathematical knowledge. However, their understandings of mathematical concepts, process of learning mathematics and proper usage of mathematical ideas are mostly at the surface level, rather than deep understanding. In addition to this, students already have the idea that mathematic as a difficult subject. The difficulties in acquiring the mathematic skills and concepts may deteriorate if the teaching and learning process remain ineffective for the students (Noor et al. 2018).

That has motivated us to the development of this learning tool, specifically on vector calculus topic. The intention is to help student to focus more on analyzing the mathematical problem and finding ways to solve it, rather than working on calculation. They of course must possess all the basic knowledge on how the solutions work manually, but with the assistance of that learning tool, learning process can be very enjoyable. The focus of this study is measure the prospect of engaging a learning tool in teaching and learning of mathematical engineering subject. It is done by investigating the students' perceptions towards the learning tool and measuring the readiness of using the learning tool in classroom. Research by Ünal et al. (2014), Anuar et al. (2016), Nasir and Ismail (2016) and Akaslan and Law (2011) shows that instructor and students have some level of readiness in using technology in teaching and learning, across many areas. 
INTERNATIONAL JOURNAL OF ACADEMIC RESEARCH IN BUSINESS AND SOCIAL SCIENCES

Vol. 9, No. 7, July, 2019, E-ISSN: 2222-6990 C 2019 HRMARS

\section{Methodology}

This study was conducted in 2 years, from the development of the learning tool to analysis of the result. Table 1 shows the research flow of this study. Phase I and II are already completed where the tool was developed using Maple 2016 (Noor et al. 2018). In this study, phase III (a), refers to pre-test, where students were asked to answer a set of questions from vector calculus topic manually. Then in phase III (b), they were introduced to the tool and were given the opportunity to use it by answering the same set of questions previously. Once completed, they were given a link to answer an online survey to evaluate the learning tool.

Table 1. Summary of the Research Flow

\begin{tabular}{ll}
\hline & \multicolumn{1}{c}{ Activities } \\
\hline Phase I & $:$ Preliminary survey \\
Phase II & $: \begin{array}{l}\text { Development of the application on each topic of the } \\
\text { subject } \\
\text { a. Pre-test }\end{array}$ \\
Phase III $\quad:$ & b. Test run the application \\
Phase IV $\quad:$ C. Post-test & Analysis
\end{tabular}

Fig 1 to Fig 4 depicted the interface of the tool. Students are able to answer some questions on gradient, curl and divergent of vector field. As shown in Fig 1, students need to enter the scalar function either in 2 or 3 variables. By pressing the solve-for-gradient, the answer will be displayed at the right hand side column. With certain input values, we can determine the vector field at any particular point. Illustrated in Fig $\mathbf{2}$ is the interface for solving divergent and curl of a vector field. The solution given, will determine whether a vector field is compressed or incompressible, source or sink, rotational or conservative. The application also allows students to plot the vector field as shown in Fig 3. The image is rotatable by simply moving your curser to view the vector field in a different angle or axis. Besides that, students can also evaluate line integral of a vector field in 2 or 3 variables for moving a particle from one point to another point along a straight line, as described in Fig 4.

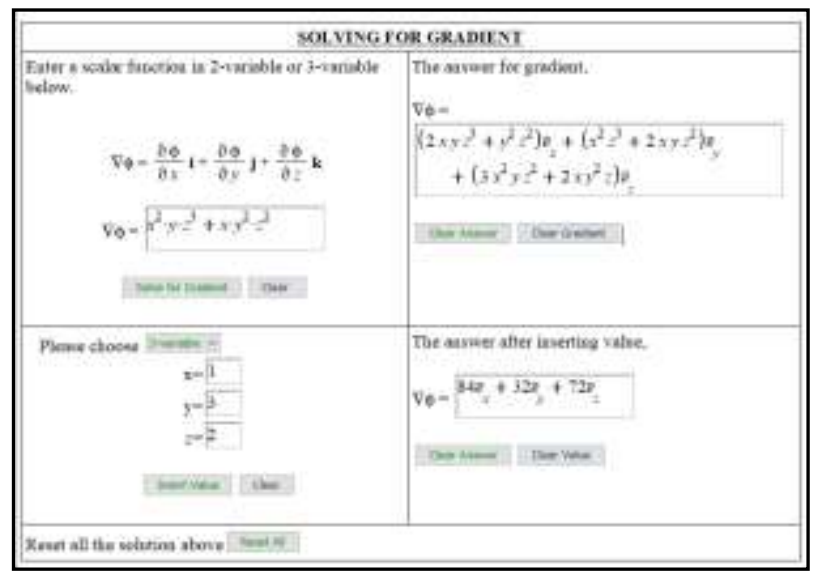

Fig. 1 Interface for solving gradient of function in 3 variables 
INTERNATIONAL JOURNAL OF ACADEMIC RESEARCH IN BUSINESS AND SOCIAL SCIENCES

Vol. 9, No. 7, July, 2019, E-ISSN: 2222-6990 @ 2019 HRMARS

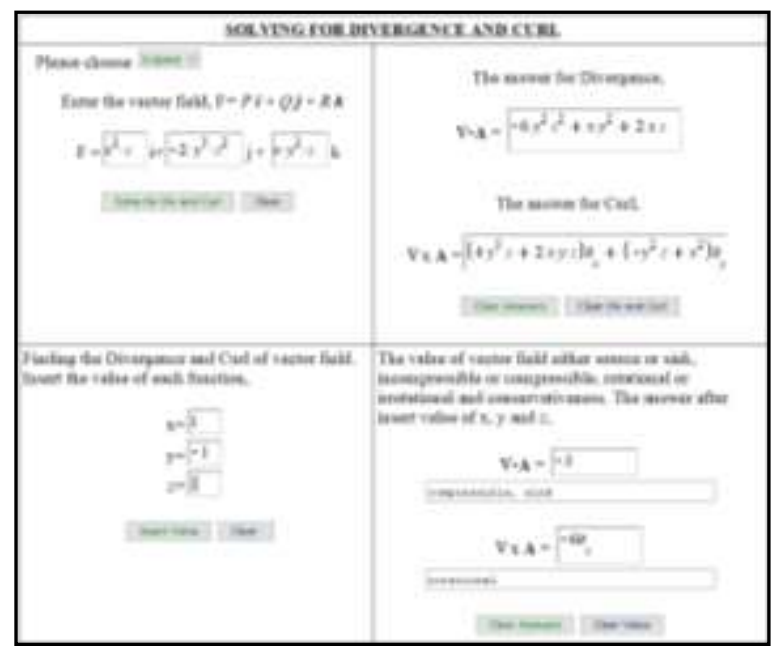

Fig. 2 Interface for solving divergent and curl for 3-space vector field

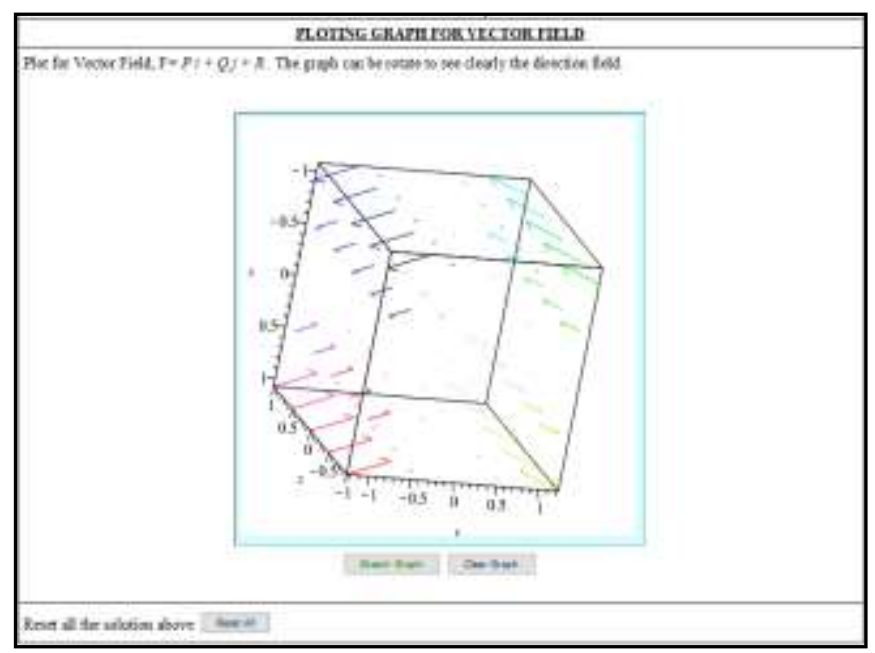

Fig. 3 Plotting graph of vector field in 3-space

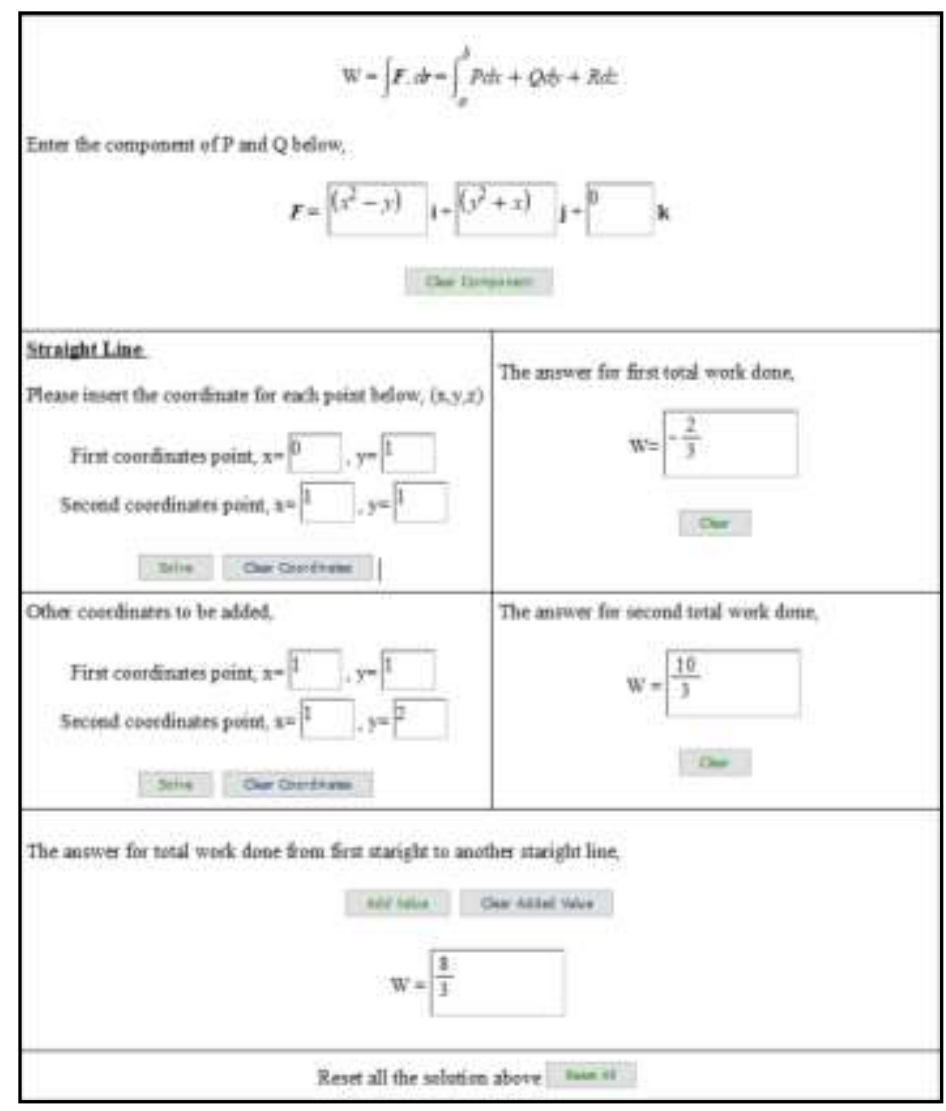

Fig. 4 Interface for solving line integral 
INTERNATIONAL JOURNAL OF ACADEMIC RESEARCH IN BUSINESS AND SOCIAL SCIENCES Vol. 9, No. 7, July, 2019, E-ISSN: 2222-6990 @ 2019 HRMARS

This study used a convenience sampling method where respondents are selected because of their convenient accessibility and proximity to the research. An online survey from was used as the quantitative data collection instrument. The survey contains 3 parts. The first part was to obtain their demographic details. Meanwhile, part two was to investigate the students' perceptions on the learning tool. There are 3 aspects to be evaluated based on perceptions, which are package screen, terminology and system information as well as perceived usefulness. The last part was to evaluate the students' readiness in utilizing the learning tool in classroom for solving vector calculus problems. Students were also asked to report their perception and readiness for the tool to be implemented in class.

There are a number of measurement instruments available as reported by Ann and Doculan (2016) in assessing the level e-learning of readiness. But in this study, the model used was established by Aydın and Tasci (2005). Akaslan and Law (2011) and also Ünal et al. (2014) adopted this model in their study. This model is adaptable because both E-Learning and our learning tool can be considered as instructional content delivered by electronic technology. The survey items were measured based on 5-point Likert scale together with some free text boxes for the students to answer some subjective questions. The Likert scale of 1 being "Very Disagree" and 5 refers to "Very Agree". The model developed by Aydın and Tasci (2005) defines a mean score of less than 3.40 as low level of readiness and requires a lot more work or some work to be done. A mean score in between 3.41 to 4.20 is categorized as a satisfactory level of readiness but requires a few improvement. Meanwhile, a score more than 4.21 shows a very good level of readiness. Thus, based on this model, the anticipated level of readiness for the learning tool to be implemented is with a mean score of 3.41, which was determined by 4 intervals of readiness with 5 levels in Likert scale.

\section{Results and Discussion}

A group of 40 students took part in this study. From the survey, it is recorded that $52.5 \%$ are male student and $47.5 \%$ are female, which is quite common in any Engineering programme that male students are generally larger in number compared to female students. Result shows that $32.5 \%$ spend more than 4 hours a day on computer, while $27.5 \%$ spend in between 2 to 4 hours. Only $20 \%$ of the respondents spend less than 1 hour and in between 1 to 2 hours, respectively. With the amount of hours spend daily on computer; it also reflects their depth knowledge in computer software. $62.5 \%$ have fair depth knowledge in computer software, with $15 \%$ recorded very good and about $2.5 \%$ recorded as excellent. Analysis of the quantitative data was made based on the evaluation criteria as shown in Table 2.

There are three components on finding the students' perceptions on the learning tool, that is 'Package Screen', 'Terminology and System Information' and also the 'Perceived Usefulness'. The mean score for each component, as well as the sub component is shown is Table 1. The grand mean score, $\bar{X}$ for 'Package Screen' is 3.96, indicate that the students are satisfied with screen view but need some improvement. The lowest mean score for subcomponent of 'Package Screen' is 3.88, comes from 'syntax inputs', which is the input box where the students key in the function or vector field. Maple is characters sensitive. Any functions that involve multiplication require students to use asterisk, given by the symbol '*'. For example, to enter a function of $2 x y z$, students should enter $2 * x * y * z$. The manual of using the learning tool has been given to students prior testing. 
INTERNATIONAL JOURNAL OF ACADEMIC RESEARCH IN BUSINESS AND SOCIAL SCIENCES Vol. 9, No. 7, July, 2019, E-ISSN: 2222-6990 @ 2019 HRMARS

The grand score for "Terminology and System Information" is recorded as 3.94, indicates that students are satisfied with some room of improvement. It also shows that the words used and the system data are acceptable and suitable. The subcomponent 'system is suitable for all users' obtained the lowest score that is 3.75 . It is undeniable fact that the learning tool is only meant for student taking vector calculus subject. The 'Perceived Usefulness' component recorded a grand mean score of 4.30. It shows that students have good level of readiness. There are a set of questions aimed to measure the students' readiness of using the learning tool in classroom.

Table 2. The Survey Mean Score of the Students' Perceptions on the Application

\begin{tabular}{lc}
\hline \multicolumn{1}{c}{ Evaluation Criteria } & Mean \\
\hline Package Screen & \\
The readability of characters & 3.95 \\
The organization of information & 4.00 \\
The sequence of actions & 3.95 \\
The syntax of inputs & 3.88 \\
The display design & 4.03 \\
\hline
\end{tabular}

\begin{tabular}{|c|c|}
\hline \multicolumn{2}{|l|}{ Terminology \& System Information } \\
\hline The prompts for input is clear & 4.00 \\
\hline The system is user friendly & 3.97 \\
\hline The system speed is fast enough & 3.87 \\
\hline The system is suitable for all users & 3.75 \\
\hline Terminology \& System Information $\bar{X}$ & 3.94 \\
\hline \multicolumn{2}{|l|}{ Perceived Usefulness } \\
\hline $\begin{array}{l}\text { I can easily evaluate the solution for curl and divergence for } \\
\text { vector field in } 2 \text { dimension }\end{array}$ & 4.25 \\
\hline $\begin{array}{l}\text { I can easily evaluate the solution for curl and divergence for } \\
\text { vector field in } 3 \text { dimension }\end{array}$ & 4.30 \\
\hline I can easily sketch a vector field & 4.30 \\
\hline $\begin{array}{l}\text { I can easily evaluate the line integral of any vector field } \\
\text { along a straight line }\end{array}$ & 4.38 \\
\hline I can accomplish task more quickly & 4.25 \\
\hline Perceived Usefulness $\bar{X}$ & 4.30 \\
\hline
\end{tabular}

Table 3 shows the mean score and grand mean score obtained for the evaluation criteria. Generally, students are satisfied with the learning tool with a grand mean score of 4.11 . It is higher than the anticipated mean of 3.41 from the E-learning Readiness Assessment Model. But anyway, the 
INTERNATIONAL JOURNAL OF ACADEMIC RESEARCH IN BUSINESS AND SOCIAL SCIENCES Vol. 9, No. 7, July, 2019, E-ISSN: 2222-6990 @ 2019 HRMARS

score also indicates that the tool requires a few improvements. It is also recorded that all criteria has mean score that is more than 3.40 . A total of $77.5 \%$ students agreed to recommend this tool to students from different groups. Also, result shows that more than half of the student rated this tool at 80 to 100 percent of satisfactory level. Table 4 lists some of the students' comments on this tool. Comments on 'fast', 'easy', 'convenient', and 'good' appear several times shows that students really enjoy utilizing the tool.

Table 3. The Survey Mean Score of the Students' Readiness on using the Application

\begin{tabular}{lc}
\multicolumn{1}{c}{ Evaluation Criteria } & Mean \\
\hline Learning to operate the tool is easy for me & 3.98 \\
I can inquire the tool to do what I want it to do & 3.98 \\
The tool is clear and understandable & 4.15 \\
The tool is flexible to interact with & 3.98 \\
Evaluating curl and divergence is very easy and convenience & 4.28 \\
Evaluating gradient of a function is very easy and convenient & 4.13 \\
$\begin{array}{l}\text { Evaluating line integral for a vector field along a straight line is } \\
\text { very easy and convenient }\end{array}$ & 4.23 \\
I believe the tool can increase my understanding in vector & 4.15 \\
calculus & \\
I believe the tool enables the lecturer to deliver the subject \\
better
\end{tabular}

Among comments from respondents on the learning tools are good; very helpful and functional; easy to understand; very easy to use; user friendly; convenience for students to complete their task and exercises; fast and easy and very helpful. It is our intention to improve the learning tool as it could benefit student taking vector calculus subject.

\section{Conclusion}

We have developed an alternative learning tool for engineering student to learn mathematics, on selected topic involved gradient, curl and divergence, plotting vector field and evaluating line integral across a straight line. The manual calculation of these topics are already complicated, therefore with the help of this tool, student can focus more on understanding the problems. This study deals with the evaluation of that learning tool. Result from the survey shows that students are ready to use the 
INTERNATIONAL JOURNAL OF ACADEMIC RESEARCH IN BUSINESS AND SOCIAL SCIENCES Vol. 9, No. 7, July, 2019, E-ISSN: 2222-6990 @ 2019 HRMARS

tool in classroom. Result has also proven that, prospect of using learning this tool in classroom is very promising which could provide interesting learning environment. It helps increase the students' interest and understanding on the specific topic. The tool can also be used during their non-face to face study as a self-check. Further study should include measuring the student achievement in tests and examination after utilizing the tool. As a future work, it is our intention to make this learning tool easily accessible for those taking vector calculus subject.

\section{Acknowledgement}

This research is funded by the Institute of Research Management \& Innovation (IRMI), Universiti Teknologi MARA Malaysia (UiTM) under the ARAS Grant (600-IRMI/DANA5/3/ARAS (0184/2016). The authors would like to thank the IRMI, UiTM and all lecturers, students, research assistants and other individuals who are either directly or indirectly involved in this project.

\section{References}

Abdulameer, A., Sulaiman, M., Aras, M. S. M., \& Saleem, D. (2016). GUI Based Control System Analysis using PID Controller for Education. Indonesian Journal of Electrical Engineering and Computer Science.

Adam, N. L., Alzahri, F. B., Cik Soh, S., Abu Bakar, N., \& Mohamad Kamal, N. A. (2017). Self-Regulated Learning and Online Learning: A Systematic Review (pp. 143-154). Springer, Cham.

Akaslan, D., \& Law, E. L.-C. (2011). Measuring teachers' readiness for e-learning in higher education institutions associated with the subject of electricity in Turkey. In 2011 IEEE Global Engineering Education Conference (EDUCON) (pp. 481-490). IEEE.

Almanasreh, H. (2017). e-Learning Mathematics. Retrieved from http://arxiv.org/abs/1709.05211

Ann, J., \& Doculan, D. (2016). E-Learning Readiness Assessment Tool for Philiphine Higher Education Institutions. International Journal on Integrating Technology in Education (IJITE), 5(2).

Anuar, R., Zakaria, W. Z. W., Noor, H. M., \& Othman, N. F. (2016). TPACK in VAE: A Study on Students' Readiness to Use E-Learning in the Teaching and Learning of Visual Art Education. In 7th International Conference on University Learning and Teaching (InCULT 2014) Proceedings (pp. 811-822). Singapore: Springer Singapore.

Aydın, C. H., \& Tasci, D. (2005). Measuring Readiness for e-Learning: Reflections from an Emerging Country. Journal of Educational Technology and Society, 8(4), 244-257.

Hussain, R. M. R. (2004). Elearning in Higher Education Institutions in Malaysia. Retrieved from http://ldms.oum.edu.my/oumlib/sites/default/files/file_attachments/odlresources/4322/elearning-higher.pdf

Jono, M. N. H. H., Hasanordin, R., Salleh, S., Ibrahim, M., Aziz, A. A., \& Asarani, N. A. M. (2016). Measuring of Effectiveness of Courseware Content Using Learning Theory for a Programming Subject. In Envisioning the Future of Online Learning (pp. 193-202). Singapore: Springer Singapore.

Naidoo, K. \& Naidoo, R. (2007). First year students understanding of elementary concepts in differential calculus in a computer laboratory teaching environment. Journal of College Teaching and Learning, 4(9), 55-69. 
INTERNATIONAL JOURNAL OF ACADEMIC RESEARCH IN BUSINESS AND SOCIAL SCIENCES

Vol. 9, No. 7, July, 2019, E-ISSN: 2222-6990 @ 2019 HRMARS

Nasir, N. F. W. M., \& Ismail, I. S. (2016). Student Readiness of a Newly-Designed Blended Learning English Language Proficiency Course in UiTM. In 7th International Conference on University Learning and Teaching (InCULT 2014) Proceedings (pp. 777-788). Singapore: Springer Singapore.

Noor, N. M., Sulaiman, H., Alwadood, Z., Halim, S. A., Wahid, N. F. S., \& Ab Halim, N. A. (2018). Development of learning tools using maples for engineering mathematics subject. Indonesian Journal of Electrical Engineering and Computer Science, 9(1), 131-138.

Osman, R., \& Pa, N. A. N. (2015). Conceptions of Mathematics among Diploma in Actuarial Science Students. Journal of Management Research, 7(2), 266.

Ozyurt, O., Ozyurt, H., Baki, A., \& Güven, B. (2013). Integration into mathematics classrooms of an adaptive and intelligent individualized e-learning environment: Implementation and evaluation of UZWEBMAT. Computers in Human Behavior, 29(3), 726-738.

Prakash, A. P., Jerlin, J. E., \& Fernandes, J. B. (2014). A Study on the Causes for Failures in Mathematics by Engineering Students Using CFRM Model. In Proceedings of the World Congress on Engineering 2014. Retrieved from http://www.iaeng.org/publication/WCE2014/WCE2014_pp29-33.pdf

Rosenberg, M. J. (2006). Beyond E-Learning - Approaches and Technologies to Enhance Organizational Knowledge, Learning, and Performance (Vol. 94). Pfeiffer.

Unal, Y., Alir, G., \& Soydal, I. (2014). Students Readiness for E-Learning: An Assessment on Hacettepe University Department of Information Management (pp. 137-147). Springer, Berlin, Heidelberg.

Zakaria, E., \& Salleh, T. S. (2015). Using Technology in Learning Integral Calculus. Mediterranean Journal of Social Sciences, 6(5).

Corresponding Author:

Email: norlenda@tmsk.uitm.edu.my 